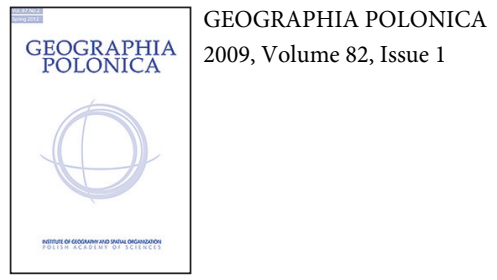

\title{
THE INFLUENCE OF AN URBANIZED AREA ON THE REGIME OF RIVER DISCHARGES IN THE LUBLIN AGGLOMERATION
}

\author{
ZDZISŁAW MICHALCZYK, JOANNA SPOSÓB \\ Department of Hydrography \\ Institute of the Earth Sciences \\ Maria Curie-Skłodowska University \\ Akademicka 19, 20 - 033 Lublin, Poland \\ E-mails: joanna.sposob@poczta.umcs.lublin.pl; zdzislaw.michalczyk@poczta.umcs.lublin.pl
}

\begin{abstract}
This study presents changes in water conditions in the Lublin agglomeration, especially as regards discharges from the Bystrzyca and other rivers. Areas covered with impermeable materials, such as asphalt and concrete, have caused changes in directions of surface runoff and an intensification of this process, with effects on the discharges of rivers. The regime of flooding is the consequence of natural and anthropogenic conditions. Spring and summer floods in Lublin and at water gauges below the city are mainly caused by surface runoff from the urban area. During periods of snowmelt periods or torrential rain, water flows rapidly through the system of stormwater drainage, and then into the rivers.
\end{abstract}

Key words: anthropopressure, river discharges, floods

\section{INTRODUCTION}

The process of urbanization has a considerable hydrological impact, especially in the way that it influences the nature of runoff. Urbanized areas are places of modification to the typical distribution of elements making up the water balance. The removal of vegetation, mass construction of houses and industrial areas, drilling of wells, increase of population requiring establishment of new water supply and distribution systems, construction of sanitary drainage systems and treatment plants for wastewaters and construction of stormwater drainage systems all have consequences for the water conditions in a river basin. Some of the impacts, such as a decrease in transpiration and an increase in storm flow, a slight lowering of the wa- ter table and some contamination are to be observed in the first, early stage of urban growth. Reduced infiltration and a lowered water table, higher flood peaks and lower low flows, increased pollution of streams and wells can all be found in the stages of urban development known as middle-urban and late-urban (Goudie 2000).

The impact of urbanization can be related to three groups of issues: water resources, water quality control, and flood control (Hall 1984). Concentration of inhabitants and consumers of water has brought about both quantitative and qualitative changes in surface and underground waters. The exploitation of underground waters has led to the generation of a wide depression funnel. Its range and depth have changed with the level of atmospheric precipitation and abstraction 
of water from underground. The installation of sewerage and stormwater drainage accelerates runoff. Impermeable surfaces of bitumen, tarmac, tiles and concrete favor floodrunoff increases in comparison with rural sites; changing the directions of surface runoff and intensifying this process, with effects on the discharges of rivers.

\section{CONDITIONS OF WATER OCCURRENCE IN THE BYSTRZYCA BASIN}

Lublin, the largest urban centre in eastern Poland, was founded on the River Bystrzyca, at the mouths of its tributaries: the Czechówka and the Czerniejówka (Fig. 1). The Bystrzyca basin, and especially the part thereof in Lublin, is characterized by a high level of exploitation of water resources. Hydrographically and hydrogeologically, these are areas with complex conditions of water circulation in which a hydraulic connection between surface and groundwaters is found. In the Bystrzyca basin of area $1,315.5 \mathrm{~km}^{2}$, there are almost 500,000 habitants, 360,000 in Lublin alone. This is an area of current and complex problems regarding the supply of water for consumption and industrial purposes, recreational use, urbanization and protection of the natural environment. Where land-use structure is concerned it isf agricultural areas that are dominant with $70.7 \%$ arable land, $4.1 \%$ meadows and pastures, and $3.0 \%$ orchards. Forests account for just $10.8 \%$ of the basin area. The share of waters is very small; reservoirs occupying just $0.32 \%$ of the area, rivers $0.22 \%$. Considerable areas of land in the basin are occupied by roads $-2.6 \%$, railways $-0.6 \%$ and urban areas $-5.2 \%$ (Michalczyk 1997). Soils and Quaternary surface deposits are of good permeability, something that favors the infiltration of water into the saturated zone.

The Bystrzyca flows out from fissurelayer springs in Sulów, and in its middle course it flows through Lublin. The Bystrzyca is a left-bank tributary of the Wieprz, the main river in the Lublin Upland (Fig. 1). The

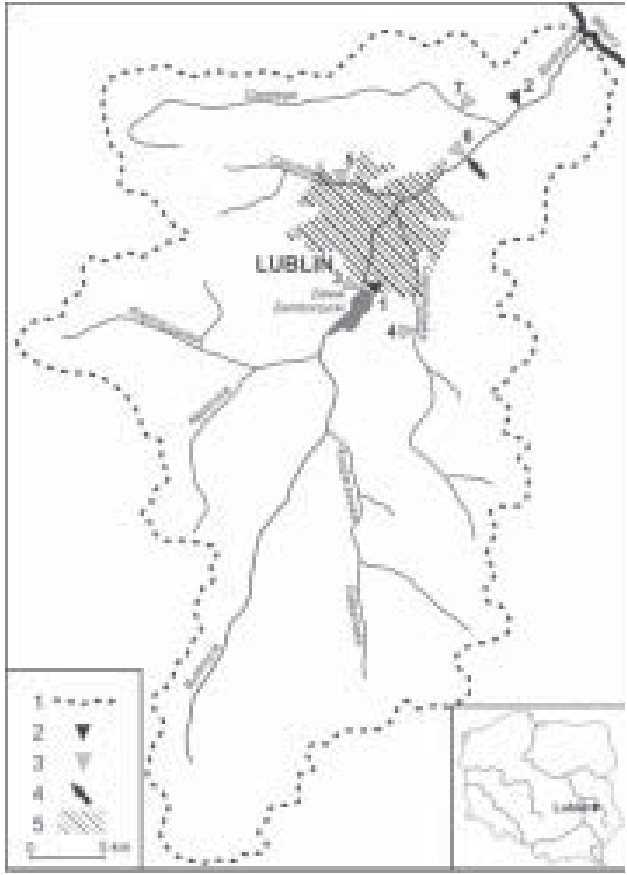

Fig. 1. Location of Lublin in the Bystrzyca basin. 1 - water divide, 2 - water gauges of the Institute of Meteorology and Water Management, 3 - water level dataloggers of the Department of Hydrography UMCS, 4 - discharge point for water from the sewage treatment plant, 5 - urbanized area.

level of water resources, counted as the average value for outflow from the Bystrzyca is of almost $5.0 \mathrm{~m}^{3} / \mathrm{s}$, which corresponds to a specific runoff of $3.87 \mathrm{l} / \mathrm{s} \cdot \mathrm{km}^{2}$. The share of underground alimentation is $76 \%$ of the total outflow. For the whole Bystrzyca basin, the estimated surface and underground water resources (concerning seasonal and annual variability of discharges) in a reliable year are 58.4 million $\mathrm{m}^{3} /$ year (Michalczyk 1997).

In the geological structure and water conditions of the basin, it is the carbonated rocks of the Upper Cretaceous developed as opokas, marls and limestones that are the most important. They can be found across the area, waters circulating in those rocks creating the one and sometimes only aquifer (Michalczyk 1986). The abundance of the carbonate rocks in water depends on the den- 
sity and size of fissures, whose permeability to water is at least ten times greater than porous rocks. Carbonate deposits of the Cretaceous, locally also Paleocene materials, are covered by a thin layer of postglacial sands of various granulometry, or else by dusty deposits. The infiltration conditions for precipitation are good, in spite of the diversity of surface relief, this being a consequence of the high permeability of surface deposits, and something that is reflected in a low-density river network.

Useful aquifers in the Bystrzyca basin are found in fissured rocks of the Upper Cretaceous and the Paleocene, as well as in sandy - gravel Quaternary deposits. Groundwaters form one reservoir in which Cretaceous, Tertiary and Quaternary waterbearing beds and multiaquifer formations are hydraulically connected, this resulting in abundant and steady feeding of rivers by groundwater, and infiltration of surface waters into the areas of depression funnels. There is one water table in the basin, inclined toward the Bystrzyca and its tributaries. In natural conditions, groundwaters remain in drainage balance with surface waters. In the river valleys, groundwaters occur superficially below the surface of the floodplain. On the lower parts of the slopes, the thickness of the unsaturated zone is of several meters, while it reaches 30-50 meters on the hilltops. Groundwaters of the Bystrzyca basin have a chemical composition typical of the aquifer formed in the chalk rocks. There are mainly bicarbonate-calcium or bicarbonate-calcium-magnesium waters of neutral reaction, moderately hard and hard. The good quality of groundwater points to just the initial stage of transformation of their natural composition.

\section{CHANGES IN WATER CONDITIONS IN LUBLIN}

The groundwaters exploited in the Lublin area that are of good quality circulate in the Maastricht marls and opokas. Their high quality is the result of a prolonged process of seepage in the rocks. The slow flow of water in the main aquifer of the Bystrzyca river basin, lasting between approx. several years and over 100 years was identified on the basis of the low concentration of tritium (Zuber et al. 2001). Natural conditions: the shallow occurrence of groundwaters, high-capacity wells, favorable physico-chemical properties of water, and limited surface water resources were all reasons to exploit groundwater. Rivers in the Lublin area have rather small catchments, so discharges are not high, averaging about $3 \mathrm{~m}^{3} / \mathrm{s}$, and during low flows not reaching even $1 \mathrm{~m}^{3} / \mathrm{s}$. Thus, in urban areas surface waters are subject to the inflow of various contaminants and pollutants into the valleys and channels of the rivers, especially in the heavy urbanized and industrialized districts of the city.

Estimates of the degree to which water conditions had changed were based on rich archival materials of the Department of Hydrography of Maria Curie-Skłodowska University in Lublin; published and archival data of the Institute of Meteorology and Water Management; data from the Municipal Company for Water Supply and Sewage Treatment and field observations and measurements. Maps of the groundwater table in the Lublin area for the summer seasons of 1955, 1960, 1972, 1981 and 1995 were collected (Michalczyk 1997). Groundwaters occurring in the bottom of the Quaternary deposits on the hilltops and slopes were intensively exploited to the end of the 1950s and are no longer found because of water abstraction, the building of several deep wells, and changed infiltration conditions. Large urban areas were taken for municipal and industrial buildings as well as roads and hardened playgrounds. The conditions for water infiltration also became worse in green areas because of soil compaction. Precipitation waters are now carried away immediately from built-up areas (covering $43.3 \%$ of the city area as of 2005) by way of the stormwater drainage system. The area of agricultural land decreased to $39.7 \%$ and forests to $11.5 \%$, while waters occupy only 


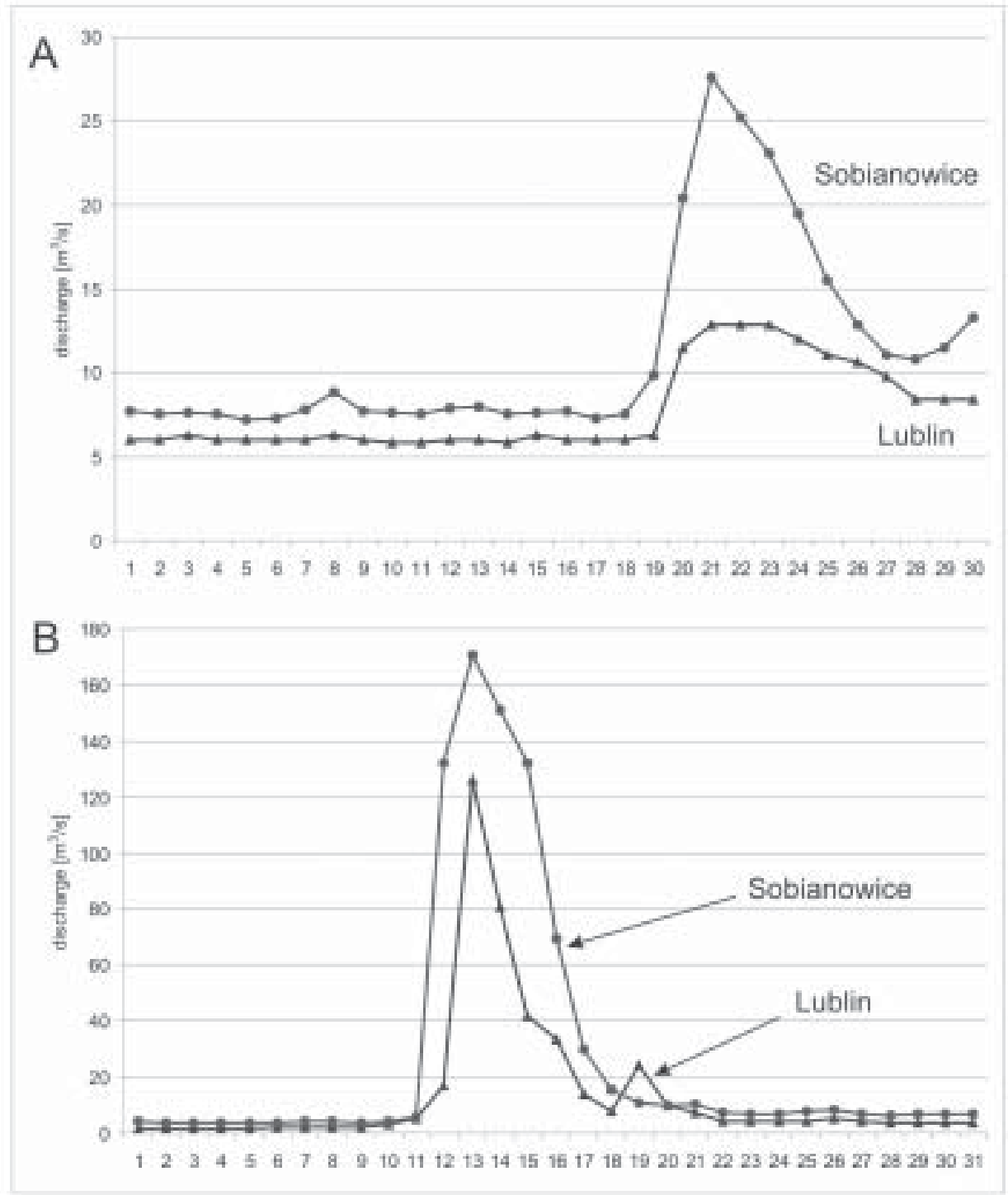

Fig. 2. Discharges of the Bystrzyca River at the Lublin and Sobianowice water gauges during the snowmelt periods of March 2003 (A) and April 1999 (B).

$2.8 \%$ of the city area. Due to city development, some urban areas are characterized by limited infiltration because of building up plus ground compaction.

Municipal and industrial water intakes existing in the Lublin region only use groundwater resources circulating in fissured rocks of the Upper Cretaceous and
Paleocene. The groundwater intakes concentrated in the Lublin region supply over $90 \%$ of the whole groundwater abstraction in the Bystrzyca basin. Only small amounts of water are taken in outside Lublin. The main feature of the water intakes in the Lublin area is their concentration on relatively small area. Long exploitation of groundwa- 
ters resulted in forming of wide depression funnel for all groundwater intakes. On the main part of the Lublin depression funnel groundwater table is almost flat, especially in the zones of the river valleys. It can be explained by widening of fissures in the zones of intensive flow of water feeding particular water intakes. The widest range of the funnel, exceeding $200 \mathrm{~km}^{2}$, with depression of over 10 meters, was observed in the early nineties of the last century, with exploitation rate of 50 million $\mathrm{m}^{3} /$ year. In subsequent years a slow process of the infilling of the depression funnel and of a decline in its range was observed (Michalczyk 1997), this being the result of slightly greater atmospheric alimentation, as well as more lower exploitation of groundwater resources. In 1995, a lowered water table was reported over an area of about $170 \mathrm{~km}^{2}$, with exploitation of 40 million $\mathrm{m}^{3} /$ year. In the main part of the city depression funnel there was a shallow, groundwater table lowered by over 4 meters over an area of 40 $\mathrm{km}^{2}$. In following years that area decreased and shallowed thanks to enhanced atmospheric supply. In the years 2001-2006, the area of the depression funnel was $120 \mathrm{~km}^{2}$, with exploitation at 25 million $\mathrm{m}^{3}$.

Groundwaters in the Lublin area have a strong hydraulic connection with surface waters. In natural conditions, intensive and steady feeding of river channels by groundwater is observed, but in periods of low water tables infiltration of surface water to aquifers takes place, especially in the area of depression funnel. The amount of water flowing in rivers in the city depends on alimentation in the upper course of the basin of the Bystrzyca, and its tributaries the Krężniczanka, the Czerniejówka, and the Czechówka. River waters flow through the city, and some of them feed groundwater resources. In the urban area waters from the storm drain system flow into the rivers, especially during periods of snowmelt or rain. After their use and purification, waters taken in at wells are discharged into the rivers below Lublin.

\section{CHANGES IN THE BYSTRZYCA RIVER DISCHARGES AT WATER GAUGES OF THE INSTITUTE OF METEOROLOGY AND WATER MANAGEMENT}

Evaluation of the urban area's impact on river discharges was based on analysis of hydrometric data from two water gauges of the Institute of Meteorology and Water Management, located above and below Lublin. The Wrotków water gauge (no. 1 on Fig. 1), is located below the Zemborzyce Reservoir, and closes off the area of the upper Bystrzyca river basin covering $725 \mathrm{~km}^{2}$. Below this water gauge there is the urbanized and industrialized area of Lublin, with many outlets of stormwater systems and discharged effluents from the sewage treatment plant. The water gauge in Sobianowice (no. 2 on Fig. 1), located $9.8 \mathrm{~km}$ along the Bystrzyca, closes off a catchment area of $1,265 \mathrm{~km}^{2}$. In the years $1951-2000$, the average discharge rate for the Bystrzyca at the Sobianowice gauge was of $4.98 \mathrm{~m}^{3} / \mathrm{s}$, corresponding to a specific runoff of $3.94 \mathrm{l} / \mathrm{s} \cdot \mathrm{km}^{2}$.

In Lublin, discharges of the river change in line with the state of water resources and the intensity of surface runoff. When groundwater levels are low, river discharges decrease through river water infiltration underground, while at times of high groundwater levels the discharges are higher, being augmented by water from underground. During snowmelt periods fast reaction to inflow of water from surface runoff is observed (Fig. 2AB). Surface runoff in the urban catchment appears earlier, lasts longer, and reaches higher values than that in the rural catchment.

The earlier and faster appearance of surface runoff in the urban catchment is documented for runoff of snowmelt water after a 1-day snowfall in April 1999. Surface runoff from the area of the city caused a flood along the Bystrzyca (Fig. 2B). In the rural catchment runoff was not so high because of water retention in the ground.

In the summer season, short intensive periods of rainfall cause water from the urban catchment to flow off very rapidly. Torrential rain reaching several millimeters causes an 


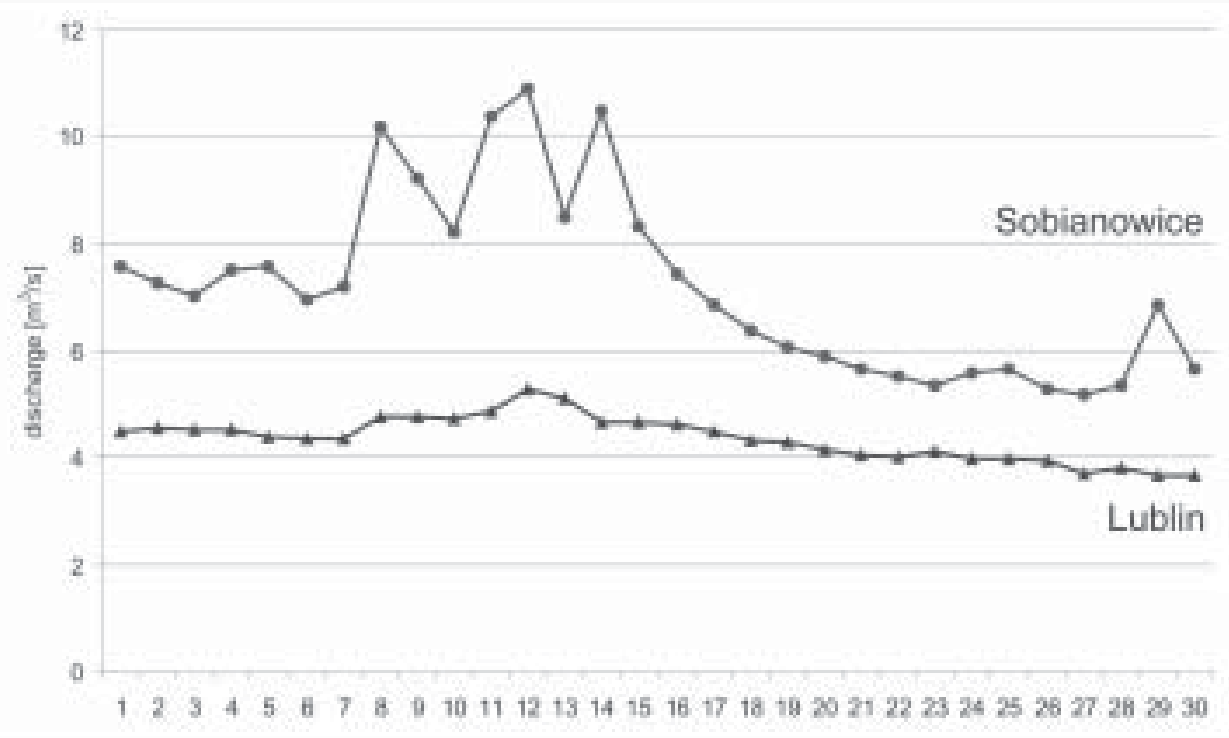

Fig. 3. Discharges of the Bystrzyca at the Lublin and Sobianowice water gauges in June 2002.

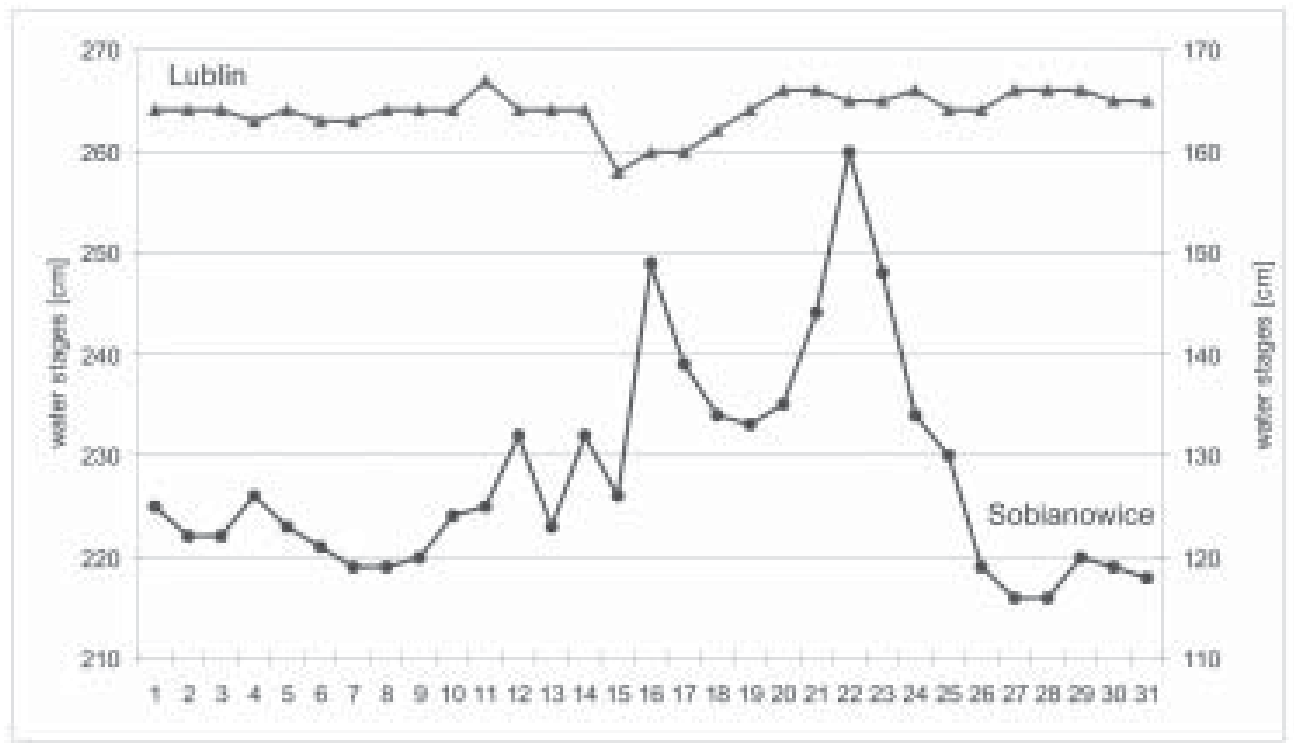

Fig. 4. Water stages of the Bystrzyca at the Lublin and Sobianowice water gauges in May 2003. 


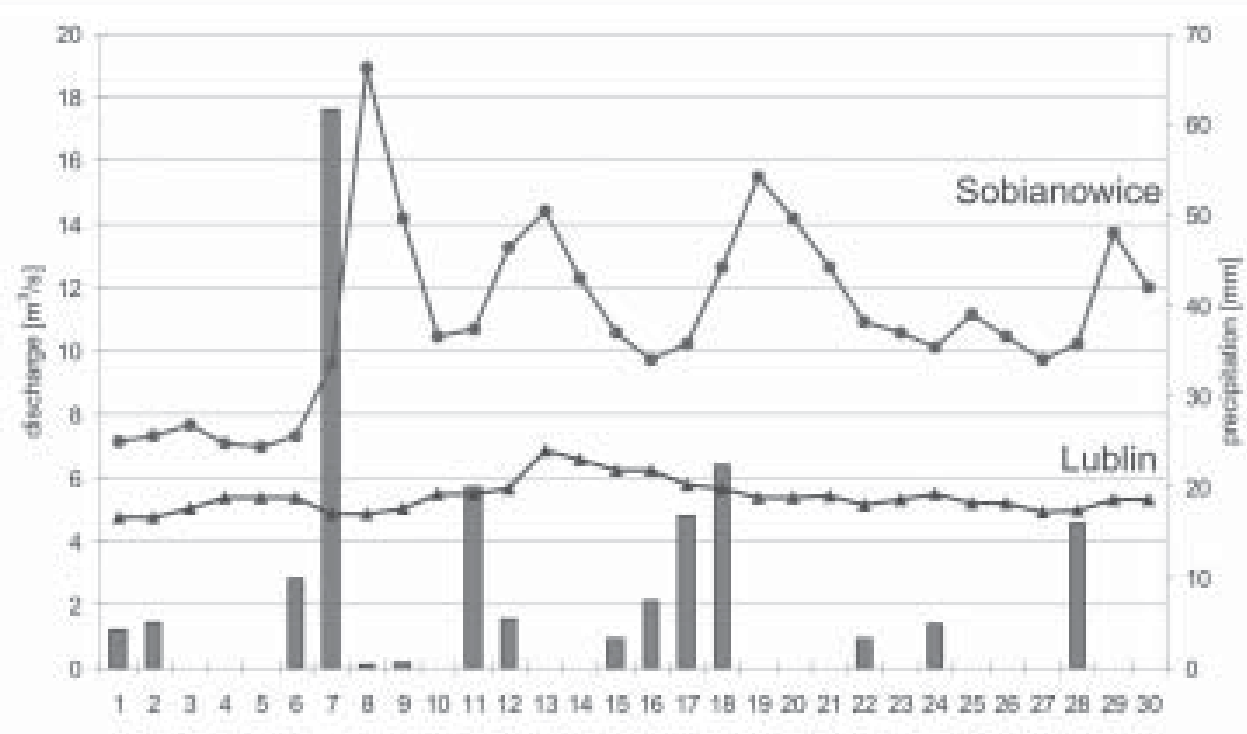

Fig. 5. Discharges of the Bystrzyca at the Lublin and Sobianowice water gauges, and precipitation in September 2001.

increase in water stages, and in discharges below the city. Figs. 3 and 5 show changes in river discharges above and below the city, while Fig. 4 presents changes in water stages at both water gauges. At Sobianowice briefly increased discharges result from rapid runoff from the urban area.

\section{CHANGES IN WATER RESOURCES IN LUBLIN AS BASED ON DISCHARGE MEASUREMENTS}

Hydrological data from the two water gauges show changes in discharges from rivers in the city area. The evaluation of the degree to which the flow of water in rivers in the Lublin area had changed was based on measurements of discharges. In the summer months of 1990 - 2006 inclusive, 21 series of river discharge measurements were produced for the Lublin area. These were done during one day (several hours) in longer rainless periods, i.e. in cases in which water in river channels was flowing from underground supply. Water gauges were located on the Lublin rivers at the limits of the depression funnel (Fig. 6). Series of data were set as the average counted from all measurements (Table 1) and divided into periods with low water resources $(1990-1997)$ or average and high (1998 - 2006). Selected years differ, not only in the value for atmospheric feeding, but also as regards the value for the rate of exploitation of groundwater resources (Table 1), as related to the size and depth of the depression funnel. First measurements of discharges were made for low groundwater resources, with a water intake of about 50 million $\mathrm{m}^{3}$, and the depression funnel covering over $200 \mathrm{~km}^{2}$. After 2000 the amount of water taken in Lublin decreased to approx. 25 million $\mathrm{m}^{3} /$ year, the area of the depression funnel reducing to $120 \mathrm{~km}^{2}$.

The collected materials show that, in summer rainless periods, rivers were not fed by groundwater resources along their urban course. Some waters infiltrate underground, as is demonstrated by the results of measurements made above and below the city. In the period 1990 - 1997 the discharge from the river decreased by $0.323 \mathrm{~m}^{3} / \mathrm{s}$, while in 
the years $1998-2006$ it increased by 0.164 $\mathrm{m}^{3} / \mathrm{s}$. Along the urban course, both river discharges and specific runoff decreased. An increase for these parameters was observed in Hajdów, below the point of discharge from the sewage treatment plant, so after the inflow of water the specific runoff reached the value observed in the rural catchment (Michalczyk 2000).

\section{RIVER DISCHARGES AT THE LIMITS OF THE URBAN AREA IN 2006}

An evaluation of the conditions and levels of surface runoff from the urban area was undertaken at the end of 2005, when four water level dataloggers rejecting water stages of rivers above and below the city were established, two of them were on the Bystrzyca river: in Wrotków (below the Zemborzyce Reservoir, above the urbanized area, no. 3 on Fig. 1) and in Hajdów (below the city, no. 6 on Fig. 1), while one was on the Czechówka river at the Skansen water gauge (a rural catchment with detached houses, no. 5 on Fig. 1), and the last was on the Ciemięga river at the Pliszczyn water gauge outside the city (no. 7 on Fig. 1). The results of observations led to an evaluation of the role of the city area in shaping the surface runoff process, as well as to an evaluation of amount and durations.

The average outflow from the urban catchment was higher than the inflow of water from the rural part of the basin, as is attested to by values for specific runoff (Table $2)$. In the period concerned infiltration of surface water underground was not observed. In 10 months of 2006, surface runoff from the selected urban catchment (Fig. 1) took place, the highest values being noted for the snowmelt period, the lowest for July, when atmospheric feeding was at only $10 \%$ of the average. The discharge of water from the Sewage Treatment Plant takes place in the urban catchment, so these are underground waters taken in the area of the Lublin depression funnel. The total amount of final effluents and inflow of water in the river gives

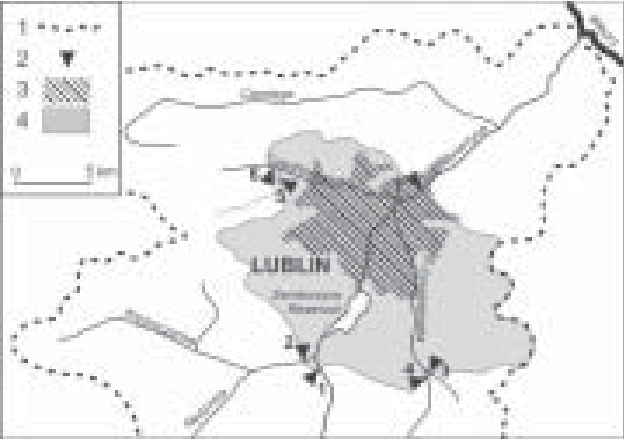

Fig. 6. Location of the urban catchment. 1 - water divide, 2 - places of discharge measurement, 3 urbanized area, 4 - urban catchment.

an average increase in discharge in the urban catchment equal to $1.88 \mathrm{~m}^{3} / \mathrm{s}$, corresponding to a value for specific runoff of $9.1 \mathrm{1} / \mathrm{s} \cdot \mathrm{km}^{2}$. This value is twice as high as that for feeding in the catchment of the upper Bystrzyca and the Czerniejówka, as well as the Ciemięga below the Lublin agglomeration.

\section{CONCLUSIONS}

Discharges from rivers change periodically as a reflection of atmospheric alimentation, amounts of taken water and water resources present in the period. Groundwaters in the Lublin area are connected hydraulically with surface waters, as is revealed in the high and steady feeding of river channels by groundwater, as well as the infiltration of surface water into aquifers, especially in the area of the depression funnel. Measurement of discharges from the Bystrzyca reveals that the period prior to intensive exploitation of groundwater resources had observed values for specific runoff almost equal in catchments above and below the city. As the result of the lowering of the groundwater table a change in the hydrodynamic balance between underground and surface waters has taken place. Feeding in the upper part of the basin determines river discharges along the urban course. River waters from the upper catchment flow through the city, and collect waters from stormwater systems, these be- 
Table 1. Discharges of rivers and specific runoff in the upper catchment of the Bystrzyca, in the urban catchment, and at the water intake in Lublin

\begin{tabular}{ccccccc}
\hline Years & $\begin{array}{c}\text { Number of } \\
\text { measurements }\end{array}$ & \multicolumn{2}{c}{$\begin{array}{c}\text { River catchment to } \\
\text { Lublin } \mathrm{A}=804 \mathrm{~km}^{2}\end{array}$} & \multicolumn{2}{c}{$\begin{array}{c}\text { Urban catchment } \\
\mathrm{A}=218 \mathrm{~km}^{2}\end{array}$} & \multirow{2}{*}{$\begin{array}{c}\text { Water intake in } \\
\text { Lublin }\left[\mathrm{m}^{3} / \mathrm{s}\right]\end{array}$} \\
\cline { 2 - 5 } & & $\mathrm{Q}$ & $\mathrm{Q}$ & $\mathrm{Q}$ & $\mathrm{q}$ & \\
\hline $1990-2006$ & 21 & 2.460 & 3.06 & -0.092 & -0.42 & 1.134 \\
$1990-1997$ & 12 & 1.786 & 2.22 & -0.323 & -1.47 & 1.318 \\
$1998-2006$ & 9 & 3.199 & 3.98 & 0.164 & 0.75 & 0.932 \\
\hline
\end{tabular}

$\mathrm{Q}$ - river discharge $\left[\mathrm{m}^{3} / \mathrm{s}\right], \mathrm{q}-$ specific runoff $\left[1 / \mathrm{s} \cdot \mathrm{km}^{2}\right]$

Table 2. Average and extreme monthly discharges in the Lublin area in 2006 [1/s]

\begin{tabular}{|c|c|c|c|c|c|c|c|c|c|c|c|c|c|}
\hline \multirow{2}{*}{ River catchment } & & \multicolumn{10}{|c|}{ Months } & \multicolumn{2}{|c|}{ Average } \\
\hline & & $\mathrm{I}$ & II & III & IV & $\mathrm{V}$ & VI & VII & VIII & IX & $\mathrm{X}$ & $\mathrm{Q}$ & $\mathbf{q}$ \\
\hline Bystrzyca to Zemborzyce & NQ & 1360 & 1360 & 990 & 2300 & 2060 & 1800 & 2100 & 1163 & 1850 & 1090 & 1090 & 1.51 \\
\hline Weir (3) & SQ & 1871 & 2048 & 5152 & 4832 & 2366 & 2651 & 2490 & 2134 & 1970 & 1633 & 2715 & 3.77 \\
\hline $\mathrm{A}=720 \mathrm{~km}^{2}$ & WQ & 3040 & 2850 & 41000 & 19600 & 2890 & 3400 & 3412 & 3412 & 2410 & 1850 & 41000 & 56.90 \\
\hline $\begin{array}{l}\text { Czechówka to Skansen (5) } \\
\qquad \mathrm{A}=56 \mathrm{~km}^{2}\end{array}$ & $\begin{array}{l}\text { NQ } \\
\text { SQ } \\
\text { WQ }\end{array}$ & $\begin{array}{l}112 \\
137 \\
144\end{array}$ & $\begin{array}{l}133 \\
203 \\
538\end{array}$ & $\begin{array}{c}49 \\
381 \\
4400\end{array}$ & $\begin{array}{c}59 \\
121 \\
346\end{array}$ & $\begin{array}{l}40 \\
57 \\
80\end{array}$ & $\begin{array}{c}13 \\
53 \\
133\end{array}$ & $\begin{array}{l}13 \\
38 \\
80\end{array}$ & $\begin{array}{c}13 \\
55 \\
133\end{array}$ & $\begin{array}{c}15 \\
51 \\
186\end{array}$ & $\begin{array}{l}22 \\
43 \\
66\end{array}$ & $\begin{array}{c}13 \\
114 \\
4400\end{array}$ & $\begin{array}{c}0.23 \\
2.05 \\
78.60\end{array}$ \\
\hline $\begin{array}{l}\text { Czerniejówka to } \\
\text { Głuszczyzna }{ }^{1 /}(4) \\
\mathrm{A}=53 \mathrm{~km}^{2}\end{array}$ & Q & 130 & 132 & 451 & 313 & 152 & 171 & 161 & 147 & 126 & 115 & 190 & 3.58 \\
\hline $\begin{array}{c}\text { Water discharge from } \\
\text { Sewage Treatment Plant } \\
(\mathrm{H})\end{array}$ & SQ & 661 & 661 & 804 & 761 & 691 & 689 & 594 & 679 & 681 & 728 & 695 & \\
\hline $\begin{array}{l}\text { Bystrzyca to Hajdów (6) } \\
\qquad A=1035 \mathrm{~km}^{2}\end{array}$ & $\begin{array}{l}\text { NQ } \\
\text { SQ } \\
\text { WQ }\end{array}$ & $\begin{array}{l}3450 \\
3694 \\
5150\end{array}$ & $\begin{array}{l}2220 \\
3475 \\
5560\end{array}$ & $\begin{array}{c}3000 \\
8388 \\
65400\end{array}$ & $\begin{array}{c}6210 \\
9158 \\
38200\end{array}$ & $\begin{array}{l}4860 \\
5184 \\
7740\end{array}$ & $\begin{array}{l}2840 \\
4336 \\
5740\end{array}$ & $\begin{array}{l}2530 \\
3340 \\
4670\end{array}$ & $\begin{array}{l}2530 \\
4733 \\
9200\end{array}$ & $\begin{array}{l}2920 \\
3577 \\
6519\end{array}$ & $\begin{array}{l}2720 \\
3126 \\
3450\end{array}$ & $\begin{array}{l}2720 \\
4901 \\
65400\end{array}$ & $\begin{array}{c}2.63 \\
4.74 \\
63.20\end{array}$ \\
\hline $\begin{array}{l}\text { Urban catchment }{ }^{2 /} \\
\qquad A=206 \mathrm{~km}^{2}\end{array}$ & SQ & 885 & 431 & 1600 & 3131 & 1918 & 772 & 57 & 1718 & 749 & 607 & 1187 & 5.67 \\
\hline
\end{tabular}

${ }^{1 /}$ Series completed from the Lublin water gauge on the Bystrzyca river, A - catchment area, NQ - lowest discharge, $\mathrm{SQ}$ - average discharge, WQ - highest discharge, Q - average discharge [1/s], q - specific runoff $\left[1 / \mathrm{s} \cdot \mathrm{km}^{2}\right],{ }^{2 /} \mathrm{urban}$ catchment counted as difference between values for Bystrzyca in Hajdów (6) and in Wrotków (3), Czerniejówka in Głuszczyzna (4), Czechówka in Skansen (5), and the discharge from Hajdów (H)

ing especially high during periods of torrential rain. In the area of the depression funnel in the city rivers do not drain groundwaters. Underground waters are taken in several wells in Lublin. Some surface waters infiltrate into the underground resources, a favorable feature for water resources when levels are lowest. After use and purification, waters taken up at wells are discharged into the rivers below Lublin. Changes in landuse structure, especially the building up of areas has been accelerating surface runoff, while renewal of groundwater resources is limited. After rainfall, discharges from the Bystrzyca increase quickly, while in the rural catchments changes in river discharges are not so rapid.

\section{ACKNOWLEDGEMENTS}

The work was supported by the Polish Ministry of Education and Science under Grant PBZ-KBN-086/PO4/2003.

\section{REFERENCES}

Goudie, A. (2000), The Human Impact on the Natural Environment, Oxford, Blackwell Publishers.

Hall, M. J. (1984), Urban Hydrology, London and New York, Elsevier Applied Science Publishers.

Łoś, M. J., Michalczyk, Z. (1984), Wpływ gospodarki wodnej Lublina na przepływy Bystrzycy [The impact of water manage- 
ment in Lublin on the Bystrzyca river discharges], Gospodarka Wodna, 1: 12 -14 .

Łoś, M. J., Michalczyk, Z. (1989), Antropogeniczne zmiany przepływu Bystrzycy $\mathrm{w}$ rejonie Lublina [Anthropogenic changes in the Bystrzyca river discharges in the Lublin area], Gospodarka Wodna, $7-8: 151-154$.

Michalczyk, Z. (1986), Warunki występowania $i$ krażenia wód na obszarze Wyżyny Lubelskiej i Roztocza [Conditions of occurence and circulation of waters in the Lublin Upland and Roztocze region], Wydawnictwo Uniwersytetu Marii CurieSkłodowskiej, Lublin.

Michalczyk, Z. (2000), Changes in circulation and the quality of water in the Lublin area, Papers of the Fourth International Conference on "Water supply, quality and protection of waters": $245-256$.
Michalczyk, Z. (ed.) (1997), A Strategy for using and protecting waters in the Bystrzyca river catchment, Wydawnictwo Uniwersytetu Marii Curie-Skłodowskiej, Lublin.

Michalczyk, Z., Łoś, M.J. (1997), Anthropogenic changes in water conditions in the Lublin area, Geographia Polonica, 68: $82-97$.

Zuber, A., Michalczyk, Z., Małoszewski, P. (2001), Great tritium ages explain the occurrence of good quality groundwater in a phreatic aquifer of an urban area, Lublin, Hydrogeology Journal, 9 (5): 451 -560 .

Papers first received: February 2007 In final form: June 2009 